Research Article

\title{
Effects of Shade and Biochar Application on the Quercetin Content of Longevity Spinach in Inceptisol
}

\author{
Angga Prasetya (D), Sri Nuryani Hidayah Utami (D), and Eko Hanudin (i)
}

Faculty of Agriculture, Universitas Gadjah Mada, Yogyakarta, Indonesia

Correspondence should be addressed to Sri Nuryani Hidayah Utami; nuryani@ugm.ac.id

Received 26 November 2020; Revised 31 March 2021; Accepted 3 April 2021; Published 15 April 2021

Academic Editor: Claudio Cocozza

Copyright ( 92021 Angga Prasetya et al. This is an open access article distributed under the Creative Commons Attribution License, which permits unrestricted use, distribution, and reproduction in any medium, provided the original work is properly cited.

Traditional medicines have been used in both developed and developing countries for a long time, one of which is longevity spinach (Gynura procumbens). Its plants are one type of plant that is used by the community to treat various diseases with their flavonoid content. This plant produces various flavonoids, such as quercetin, which can be optimized by providing shade and increasing nitrogen nutrients by giving biochar and fertilizing. This study aimed to determine the effects of biochar, shade, and fertilizer on the growth and quercetin content of Gynura procumbens plants. This research was arranged in a randomized complete block design (RCBD) with two factors. The first factor was the administration of biochar at four doses, consisting of $\mathrm{B}_{0}$ (without biochar), $\mathrm{B}_{10}$ (biochar 10 tons/ha), $\mathrm{B}_{15}$ (biochar 15 tons/ha), and $\mathrm{B}_{20}$ (biochar 20 tons/ha). Meanwhile, the second factor was the intensity of the shade with three levels of treatment, namely, $\mathrm{I}_{0}$ (without shade), $\mathrm{I}_{50}(50 \%)$, and $\mathrm{I}_{70}(70 \%)$. The results showed that the addition of 15 ton/ha of biochar with $70 \%$ shade increased the quercetin content by $0.51 \%$.

\section{Introduction}

The use of traditional medicines has been practiced in both developed and developing countries since a long time ago. According to the World Health Organization (WHO), nearly $80 \%$ of people depend on their daily medicinal needs using traditional medicines or herbal plants. The increasing use of herbal plants will increase the demand for these herbs. One of the herbal plants commonly used as herbal medicine by the community is longevity spinach (Gynura procumbens). This plant carries out metabolism producing compounds from secondary metabolites, one of which is flavonoids. According to Akowuah et al., Gynura procumbens has several potential biological activities related to the content of low molecular weight compounds such as flavonoids, saponins, terpenoids, and phenolics. These compounds are responsible for the biological activity of Gynura procumbens such as flavonoids and phenolics. However, not only is biological activity in these plants influenced by low molecular weight compounds significantly, but bioactive compounds with high molecular weight can also affect biological activity in Gynura procumbens, especially polysaccharides or carbohydrates because of their higher content in these plants. Generally, the composition of phenolic compounds obtained from plant materials is influenced by chemical properties, sample size, extraction methods, and conditions as well as the presence of contaminants from other substances [1]. According to Kaewseejam and Siriamornpun [2], Gynura procumbens consists of flavonoids (64-83\%) compared to other phenolic compounds. Polyphenol composition in Gynura procumbens consists of hydroxybenzoic acids (gallic acid, protocatechuic acid, vanilic acid, etc.), hydroxycinnamic acids (chlorogenic acid, caffeic acid, ferulic acid, etc.), and flavonoids (rutin, myricetin, quercetin, kaempferol, apigenin, etc.). The three types of polyphenols are responsible for the biological activity of the Gynura procumbens plant. One of the flavonoids produced by Gynura procumbens is quercetin. Quercetin is a class of flavonoids that exhibits several biological activities. This activity depends on the antioxidant properties of quercetin, including the ability of quercetin to capture free radicals and reactive oxygen species such as superoxide anions and hydroxyl radicals [3]. One of the elements needed to form protein in metabolism is nitrogen. Meanwhile, the soil type suitable for Gynura procumbens cultivation is Inceptisol soil. Inceptisol is young soil that is still 
developing from the parent material underneath. The type of soil that is still developing, such as Inceptisol, has a rough to a fine texture that leads to a leaching process in the soil body, thereby dissolving cations and nutrients within. According to Abdurachman et al. [4], dry soil such as Inceptisol generally has low soil fertility (low NPK). Therefore, it is necessary to add ameliorant to fulfill the nutrients needed by plants. One of the ameliorants used is bamboo biochar. Biochar is an alternative in improving soil quality to reduce $\mathrm{N}$ loss in the soil. At a temperature of $600^{\circ} \mathrm{C}$, pyrolysis produces biochar made from bamboo, nuts, and wood, which can reduce nutrient loss by $0.12 \%$ to $3.7 \%$ [5]. Bamboo biochar has a very porous structure with a large number of micropores, with an adsorption efficiency of about ten times higher than traditional wood biochar [6]. The purpose of this study was to determine the effect of biochar, shade, and fertilizer on the growth and quercetin content of Gynura procumbens plants. This research is expected to provide information to the public regarding the appropriate application of biochar, shade, and fertilizer to improve the growth and quercetin content of Gynura procumbens plants.

\section{Materials and Methods}

2.1. Description of the Study Sites. This research was conducted from January 2020 to June 2020 at the Banguntapan Experimental Field, Faculty of Agriculture, Universitas Gadjah Mada, Yogyakarta. The materials used in this study were 4-week-old cuttings of Gynura procumbens, urea fertilizer, biochar, para net (shade), and chemicals for the analysis of soil chemical properties, biochar, and quercetin compounds. The tools used in this research were bamboo, greenhouse frames, polybags, markers, label paper, hoes, stationery, sieves, and laboratory equipment in the Laboratory of General Soil and the Laboratory of Soil Chemistry and Fertility, Faculty of Agriculture, Universitas Gadjah Mada.

2.2. Soil Sampling Design and Procedure. This research was arranged in a factorial randomized complete block design (RCBD) consisting of two treatment factors, replicated three times. The first factor was the application of biochar (B) at four doses, namely, $\mathrm{B}_{0}$ (without biochar), $\mathrm{B}_{10}$ (10 ton/ha), $\mathrm{B}_{15}$ ( 15 ton/ha, and $B_{20}$ (20 ton/ha). The second factor was the intensity of the shade (I) at three different levels, namely, $\mathrm{I}_{0}$ (without shading), $\mathrm{I}_{50}(50 \%)$, and $\mathrm{I}_{70}(70 \%)$. There were 15 treatment combinations, each of which was replicated three times, thereby resulting in a total of 45 experimental units, including control.

2.3. Soil Sampling and Preparation. Land preparation started from land clearing used to arrange the polybags and given a $0 \%, 500 \%$, and $700 \%$ shade. Plant materials used were 2 month-old stem cuttings obtained from the UGM Agro Technology Innovation Center. Inceptisol soil medium was sieved $2 \mathrm{~mm}$ and then applied with biochar according to the treatment doses and then incubated for two weeks. After incubation, basic fertilizers (urea, $\mathrm{KCl}$, and SP-36) were given two days before planting. Subsequently, the plants were planted according to the various treatment combinations for two months. During the planting period, plant maintenance and observation were carried out. The maintenance included watering, pest control, and cleaning weeds. Watering was performed every afternoon to keep the soil moist. Pest control was carried out if pests were found on the plants.

2.4. Soil, Biochar, and Plant Laboratory Analysis. The soil media were analyzed to determine the content within. The analysis carried out included $\mathrm{pH}$, moisture content, soil CEC, organic $\mathrm{C}$, total $\mathrm{N}$, available $\mathrm{N}$, available $\mathrm{P}$, and base cations. Biochar, as a treatment material inserted into the soil, must be analyzed to determine its content and characteristics such as $\mathrm{pH}, \mathrm{CEC}$, moisture content, and organic C. The plant tissues, especially the leaves, were analyzed to determine the content of nitrogen and quercetin. Quercetin analysis is carried out using the chromatography method; the first thing to do is that the standard quercetin is weighed as much as $10 \mathrm{mg}$ [7]. Then, the standard is compressed into a $10 \mathrm{~mL}$ measuring flask with methanol as solvent. The main solution of $1000 \mu \mathrm{g} / \mathrm{mL}$ is taken as much as $1 \mathrm{~mL}$ and then compressed into a $10 \mathrm{~mL}$ measuring flask with methanol as solvent. A standard curve was made of the mother liquor $100 \mu \mathrm{g} / \mathrm{mL}$ by pipetting $10,30,60,120,240$, and $480 \mu \mathrm{L}$ dissolved in a $10 \mathrm{~mL}$ measuring flask with methanol solvent to mark (the standard solution content became $0.1,0.3,0.6$, $1.2,2.4$, and $4.8 \mu \mathrm{g} / \mathrm{mL}$ ). Then, filter the solution with a $0.22 \mu \mathrm{g}$ filter membrane. Inject each solution into the chromatography system as much as $20 \mu \mathrm{L}$. Furthermore, for sample preparation $25 \mathrm{mg}$ of the sample was weighed and then dissolved with methanol up to $10 \mathrm{~mL}$. Filter the sample solution with a $0.22 \mu \mathrm{m}$ filter membrane. Then, inject the sample filtrate into the chromatography system as much as $20 \mu \mathrm{L}$.

2.5. Statistical Analysis. Data from soil parameters such as moisture content, organic matter, nutrient content, $\mathrm{pH}$, CEC, and soil cations as well as plant parameters such as fresh weight, dry weight, plant height, number of leaves, and quercetin were analyzed using the ANNOVA test at a 5\% probability level using software program statistics (SPSS). Each mean value representing the replication of the three determinations was analyzed using the one-way analysis of variance $(p<0.05)$. To determine the significant difference between treatments, a further test was carried out with the Duncan test.

\section{Results and Discussion}

\subsection{Chemical and Physical Properties of Inceptisol}

3.1.1. Soil Reaction $(p H)$. Based on Table 1, the actual soil $\mathrm{pH}$ of Inceptisol in this research is 6.67, while the potential soil $\mathrm{pH}$ is 6.28. Based on Balittanah (2009), this value is categorized as neutral. The actual $\mathrm{pH}$ of the soil describes the number of $\mathrm{H}^{+}$ions measured in soil solutions only. 
TABLE 1: Chemical and physical properties of Inceptisol.

\begin{tabular}{|c|c|c|c|c|}
\hline No. & Parameter & Unit & Inceptisol & Level/category* \\
\hline 1 & Actual $\mathrm{pH}$ & - & 6.67 & Neutral \\
\hline 2 & Potential pH & - & 6.28 & - \\
\hline 3 & $\begin{array}{l}\text { Moisture } \\
\text { content }\end{array}$ & $\%$ & 6.12 & - \\
\hline 4 & Organic C & $\%$ & 1.55 & Low \\
\hline 5 & Organic matter & $\%$ & 2.18 & - \\
\hline 6 & CEC & $\mathrm{Cmol}(+) / \mathrm{kg}$ & 7.59 & Low \\
\hline 7 & $\mathrm{Ca}$ & $\mathrm{Cmol}(+) / \mathrm{kg}$ & 0.21 & Very low \\
\hline 8 & $\mathrm{Mg}$ & $\mathrm{Cmol}(+) / \mathrm{kg}$ & 0.16 & Very low \\
\hline 9 & $\mathrm{~K}$ & $\mathrm{Cmol}(+) / \mathrm{kg}^{1}$ & 0.25 & Low \\
\hline 10 & $\mathrm{Na}$ & $\mathrm{Cmol}(+) / \mathrm{kg}$ & 0.03 & Very low \\
\hline 11 & $\begin{array}{c}\text { Total N } \\
\text { Available N }\end{array}$ & $\%$ & 0.23 & Low \\
\hline \multirow[t]{2}{*}{12} & $\mathrm{NH}_{4}^{+}$ & $\mathrm{mg} / \mathrm{kg}$ & 280.61 & - \\
\hline & $\mathrm{NO}_{3}^{-}$ & $\mathrm{mg} / \mathrm{kg}$ & 420.92 & - \\
\hline 13 & $\begin{array}{c}\text { Available P } \\
\text { Texture }\end{array}$ & $\mathrm{mg} / \mathrm{kg}$ & 2.38 & Low \\
\hline \multirow{3}{*}{14} & Sand & $\%$ & 77 & \\
\hline & Silt & $\%$ & 11 & Loamy sand \\
\hline & Clay & $\%$ & 12 & \\
\hline
\end{tabular}

Note. ${ }^{*}$ Level/category is based on Balittanah 2009.

Meanwhile, the potential $\mathrm{pH}$ of the soil describes the number of $\mathrm{H}^{+}$ions in the soil solution and the soil infiltration complex so that the measured $\mathrm{pH}$ is lower. According to Damanik et al. [8], Inceptisol generally has a slightly acidic to neutral soil $\mathrm{pH}$ ( $\mathrm{pH}$ 5.6- $\mathrm{pH}$ 6.8). With a neutral $\mathrm{pH}$ in Inceptisol, the availability of nutrients will be better, and the nutrients will be adequately available for plants, thereby optimizing the plant.

3.1.2. Moisture Content. Based on Table 1, the moisture content of Inceptisol used in this research is $6.12 \%$. Inceptisol is young soil that has not been developed further so that it still contains a small amount of clay. The soil genesis process that has not been intensive causes Inceptisol to have a coarse texture and low organic matter, resulting in a low moisture-binding due to the low rate of clay formation. According to Abdurachman et al. [4], Inceptisol soil is young soil that has low organic matter content and low water holding capacity so that it has low soil fertility.

3.1.3. Organic Matter. Based on Table 1, the organic C content is $1.55 \%$, and the organic matter content is $2.18 \%$. Based on Balittanah (2009), this organic C content is categorized as low. This result is because Inceptisol is young soil that has low organic matter content. Besides, the soil was taken from moor planted with perennial crops so that very little organic material input is provided. This result is in accordance with Abdurachman et al. [4], stating that Inceptisol is young soil that has low organic matter content and low water holding capacity so that it has low soil fertility.

3.1.4. Cation Exchange Capacity. Based on Table 1, the cation exchange capacity of Inceptisol used in this research is $7.59 \mathrm{Cmol}(+) \mathrm{kg}^{-1}$, which is considered low, according to Balittanah (2009). It is because Inceptisol has a low organic matter content that causes a low CEC. Besides, Inceptisol also has low clay content and a type of kaolinite clay with a low cation exchange capacity. This result is in accordance with Hakim et al. [9] and Arifin [10], stating that the CEC is influenced by soil $\mathrm{pH}$, organic matter content, clay mineral types, and soil texture. The lower the organic matter content in the soil, the lower the cation exchange capacity.

3.1.5. Available Calcium. The Ca content in Inceptisol used in this research is $0.21 \mathrm{Cmol}(+) / \mathrm{kg}$ (Table 1 ), which is considered very low, according to Balittanah (2009). Calcium is one of the plant macronutrients in the form of cations that is important in the formation of cell walls and cell elasticity [11]. Meanwhile, $\mathrm{Ca}$ in the soil functions as a counterweight to other elements such as $\mathrm{Al}, \mathrm{Fe}$, and $\mathrm{Mn}$ [12]. The low Ca content in Inceptisol is due to the low calcium content of the parent material and leaching that causes calcium to be carried away by water, thereby resulting in low calcium content in the soil.

3.1.6. Available Magnesium. The Mg content in Inceptisol used in this research is $0.16 \mathrm{Cmol}(+) / \mathrm{kg}$ (Table 1 ), which is considered very low based on Balittanah (2009). It is because the parent material of Inceptisol is alluvial that has a low $\mathrm{Mg}$ content, and the dominant fraction of the soil is sand, thereby leading to low $\mathrm{Mg}$ content. Similar to $\mathrm{Ca}, \mathrm{Mg}$ functions as a counterweight between other elements such as $\mathrm{Al}, \mathrm{Fe}$, and $\mathrm{Mn}$ in soils that have an acidic $\mathrm{pH}$ [13].

3.1.7. Available Potassium. The available $\mathrm{K}$ content of Inceptisol used in this research is $0.25 \mathrm{Cmol}(+) \mathrm{kg}^{-1}$ (Table 1), which is low, according to Balittanah (2009). It is because the soil organic matter content contained is low, and there is no input into the soil so that it comes purely from the rock weathering.

3.1.8. Available Natrium. Based on Table 1, the sodium content is $0.03 \mathrm{Cmol}(+) \mathrm{kg}^{-1}$, which is considered very low, based on Balittanah (2009). This result is due to the low organic matter content, causing a lower source of sodium. Low sodium in Inceptisol soil is beneficial for aggregate stability and beneficial for plants. According to Foth [14], the soil is good if it contains low Na levels $\left(<1.0 \mathrm{Cmol} \mathrm{kg}^{-1}\right)$ since high sodium concentration in the soil will adversely affect the soil and plants.

3.1.9. Total and Available Nitrogen. The total nitrogen content of Inceptisol used in this research is $0.23 \%$ (Table 1), while the available nitrogen content in the form of ammonium $\left(\mathrm{NH}_{4}^{+}\right)$and nitrate $\left(\mathrm{NO}_{3}^{-}\right)$is $280.61 \mathrm{mg} / \mathrm{kg}$ and $420.92 \mathrm{mg} / \mathrm{kg}$ (Table 1), respectively. Based on Balittanah (2009), the total $N$ value is considered low. The low total nitrogen content is due to the highly mobile nitrogen and low organic matter content, thereby limiting the source of N. According to Hardjowigeno [15], nitrogen in the soil has various forms, such as protein, amino acids, ammonium, 
and nitrates. Nitrogen is absorbed by plants in its inorganic form. Ammonium is more easily adsorbed by the soil colloid surface compared to nitrate so that the movement of ammonium is slower, and the diffusion movement is low. Besides, many factors cause low nitrogen availability in the soil, such as leaching, evaporation, and the use of soil microorganisms as energy.

3.1.10. Available Phosphorus. Based on Table 1, the available $\mathrm{P}$ in Inceptisol used in this research is $2.38 \mathrm{mg} / \mathrm{kg}$, which is considered low, according to Balittanah (2009). This result is due to the unavailability of the $\mathrm{P}$ source. The organic matter content is low despite the neutral $\mathrm{pH}$, resulting in the low $\mathrm{P}$ in the soil. Soil organic matter is one of the sources of available $\mathrm{P}$ in the soil.

3.1.11. Soil Texture. Inceptisol soil used in this research is composed of $77 \%$ sand, $11 \%$ silt, and $12 \%$ clay (Table 1). Based on Balittanah (2009), it is classified in the loamy sand texture class. The domination of sand fraction is because Inceptisol is a soil that has not developed intensively. Besides, a significant clay content inhis soil profile has not been formed if, for example, to be classified as Alfisol, there must be a clay skin, so there is only a cambic horizon as the basis for the name Inceptisol.

3.2. Chemical Properties of Biochar. The $\mathrm{pH}$ of biochar is 10.33, thus, classified into the alkaline category (Table 2). This result is because, in biochar, there are alkaline cations such as $\mathrm{Ca}, \mathrm{Mg}$, and $\mathrm{CaCO} 3$ causing the $\mathrm{pH}$ of the biochar to become alkaline. According to Hua et al. [6], bamboo biochar is biochar that has high micropores, so that its adsorption efficiency can be ten times higher compared to wood and other biochar materials.

The content of organic $\mathrm{C}$ is $43.53 \%$. It is because biochar is made from both woody and non-wood plant residues that are rich in carbon. According to Putri et al. [16], biochar can bind organic $\mathrm{C}$ in the soil, making it stable and difficult to decompose. Accordingly, the content of organic C is maintained. The ash content in the biochar is $18.05 \%$. According to Maftuah and Nursyamsyi [17], the ash content is influenced by the lignin contained in the raw material and by the mineral content of the raw material that is inorganic so that it does not evaporate. The CEC value of the biochar is $11.19 \mathrm{Cmol}(-) \mathrm{kg}^{-1}$. In general, biochar has a low nutrient content and cation exchange capacity (CEC). It also has a high $\mathrm{pH}$, organic value, organic $\mathrm{C}$, and the ability to hold water so that biochar is considered as a soil improvement agent to increase soil organic $\mathrm{C}$, soil moisture content, and soil $\mathrm{pH}$ according to soil conditions.

\subsection{Effects of Biochar and Shade Application on Chemical Fertility of Inceptisol}

3.3.1. Soil Reaction ( $p H)$. The highest $\mathrm{pH}$ (7.34) was in the control treatment without biochar at $100 \%$ light intensity. Meanwhile, the lowest $\mathrm{pH}$ (5.13) was in the combination treatment of 15 ton/ha biochar and 50\% light intensity
TABLE 2: Chemical properties of bamboo biochar.

\begin{tabular}{lccc}
\hline No. & Parameter & Unit & Value \\
\hline 1 & $\mathrm{pH}$ & - & 10.33 \\
2 & Moisture content & $\%$ & 7.06 \\
3 & Organic C & $\%$ & 47.53 \\
4 & Ash content & $\%$ & 18.05 \\
5 & CEC & Cmol $(-) / \mathrm{kg}$ & 11.19 \\
\hline
\end{tabular}

(Table 3). In general, all biochar treatments showed a decrease in soil pH. According to Salawati et al. [18], amphoteric biochar has several functional groups that can act in the soil $\mathrm{pH}$ changes. Carboxyl groups as acidic properties and amino groups as alkaline properties based on soil conditions can be positively or negatively charged. Amino groups in an alkaline environment will change form to anion. Meanwhile, in an acidic environment, it will turn into a cation. This phenomenon is the cause of the decrease in soil $\mathrm{pH}$ after biochar application.

3.3.2. Organic Matter. Based on the analysis of variance, there was no significant interaction effect of biochar and shade on the soil organic matter content (Table 4). Also, the doses of biochar did not significantly affect soil organic matter content. However, there was a significant effect observed between control treatments and biochar application. The highest organic matter content resulted from the application of biochar and 50\% shade of $3.34 \%$. During the 2 -week incubation, biochar did not undergo a decomposition process, so that the organic $\mathrm{C}$ content was not significantly different. This result is in accordance with Herlambang et al. [19], stating that increasing the soil organic $\mathrm{C}$ content requires a long time, which is at least two months.

3.3.3. Cation Exchange Capacity. There was no significant interaction effect of biochar and shade on the value of cation exchange capacity (Table 5). Also, the application of biochar did not significantly affect the CEC value. The highest CEC value resulted from the control treatment at a $70 \%$ shade of $10.42 \mathrm{Cmol}(+) / \mathrm{kg}$. Meanwhile, the lowest CEC value $(8.72 \mathrm{Cmol}(+) / \mathrm{kg})$ resulted from the application of $10 \mathrm{ton} /$ ha biochar at a $50 \%$ shade. Biochar as an ameliorant can improve some soil chemical properties such as soil CEC. However, improving soil properties requires a long time, so that changes in the value of cation exchange capacity were not significantly different after the addition of biochar. Also, the low content of organic $\mathrm{C}$ and soil organic matter can be a factor in the low value of cation exchange capacity so that the ability to absorb nutrients is low.

3.3.4. Moisture Content. Based on the results of the analysis of variance shown in Table 6, the addition of biochar significantly affected soil moisture content. The highest soil moisture content $(26.83 \%)$ resulted from the application of 20 ton/ha biochar at a $50 \%$ shade, while the lowest moisture content $(22.56 \%)$ resulted from control treatment without shading. Overall, the higher dose of biochar will increase the moisture 
TABLE 3: Effects of biochar and shade application on the soil $\mathrm{pH}$.

\begin{tabular}{|c|c|c|c|c|c|c|}
\hline \multirow{2}{*}{ Shade (\%) } & \multicolumn{5}{|c|}{ Doses of biochar $\left(\right.$ ton $\mathrm{ha}^{-1}$ ) } & \multirow{2}{*}{ Mean } \\
\hline & $\mathrm{K}$ & 0 & 10 & 15 & 20 & \\
\hline 0 & $7.34 \mathrm{a}$ & $5.75 \mathrm{e}$ & $5.49 \mathrm{fgh}$ & $5.34 \mathrm{gh}$ & $5.69 \mathrm{ef}$ & 5.92 \\
\hline 50 & $6.86 \mathrm{~b}$ & $6.58 \mathrm{c}$ & $5.67 \mathrm{ef}$ & $5.13 \mathrm{i}$ & $5.52 \mathrm{fg}$ & 5.95 \\
\hline 70 & $6.83 \mathrm{~b}$ & $6.13 \mathrm{~d}$ & $5.47 \mathrm{gh}$ & $5.30 \mathrm{hi}$ & $5.43 \mathrm{gh}$ & 5.83 \\
\hline Mean & 7.01 & 6.15 & 5.54 & 5.26 & 5.55 & + \\
\hline
\end{tabular}

${ }^{*}$ Means followed by the same letters are not significantly different at 5\% DMRT.

TABLE 4: Effects of biochar and shade application on the soil organic matter (\%).

\begin{tabular}{lcccccr}
\hline \multirow{2}{*}{ Shade (\%) } & \multicolumn{3}{c}{ Doses of biochar (ton ha ${ }^{-1}$ ) } & Mean \\
\hline 0 & $K$ & 0 & 10 & 3.01 & 20 & 3.08 \\
50 & 3.18 & 2.91 & 2.42 & 2.42 & 3.07 & $2.92 \mathrm{a}$ \\
70 & 3.32 & 2.73 & 3.34 & 2.81 & 3.29 & $3.07 \mathrm{a}$ \\
Mean & 3.02 & 2.96 & 3.24 & $2.75 \mathrm{a}$ & $3.15 \mathrm{a}$ & - \\
\hline
\end{tabular}

${ }^{*}$ Means followed by the same letters are not significantly different at 5\% DMRT.

TABLE 5: Effects of biochar and shade application on the cation exchange capacity $\left(\mathrm{cmol}(+) \cdot \mathrm{kg}^{-1}\right)$.

\begin{tabular}{lcccccc}
\hline \multirow{2}{*}{ Shade (\%) } & \multicolumn{5}{c}{ Doses of biochar $\left(\right.$ ton ha ${ }^{-1}$ ) } & Mean \\
\hline 0 & $K$ & 0 & 10 & 9.51 & 90 & 9.18 \\
50 & 9.97 & 9.07 & 9.40 & 9.45 & 9.21 & $9.21 \mathrm{a}$ \\
70 & 9.56 & 9.10 & 9.72 & 9.60 & 9.39 & $9.67 \mathrm{a}$ \\
Mean & 10.42 & 9.31 & 9.64 & $9.52 \mathrm{a}$ & $9.26 \mathrm{a}$ & - \\
\hline
\end{tabular}

${ }^{*}$ Means followed by the same letters are not significantly different at 5\% DMRT.

TABLE 6: Effects of biochar and shade application on the soil moisture content (\%).

\begin{tabular}{|c|c|c|c|c|c|c|}
\hline \multirow{2}{*}{ Shade (\%) } & \multicolumn{5}{|c|}{ Doses of biochar $\left(\right.$ ton $\left.\mathrm{ha}^{-1}\right)$} & \multirow{2}{*}{ Mean } \\
\hline & K & 0 & 10 & 15 & 20 & \\
\hline 0 & $22.56 \mathrm{~g}$ & $22.59 \mathrm{e}$ & $25.96 \mathrm{~b}$ & $23.95 \mathrm{e}$ & $25.21 \mathrm{~b}$ & 24.05 \\
\hline 50 & $23.69 \mathrm{f}$ & $24.12 \mathrm{~d}$ & $22.67 \mathrm{e}$ & $23.35 \mathrm{f}$ & $26.83 \mathrm{a}$ & 22.93 \\
\hline 70 & $25.00 \mathrm{c}$ & $24.75 \mathrm{~d}$ & $22.56 \mathrm{f}$ & $23.20 \mathrm{f}$ & $22.57 \mathrm{f}$ & 23.62 \\
\hline Mean & 23.74 & 23.82 & 23.73 & 21.50 & 24.87 & + \\
\hline
\end{tabular}

${ }^{*}$ Means followed by the same letters are not significantly different at 5\% DMRT.

content in the soil. Amelioration is one of the appropriate actions to improve the soil's ability to hold and provide water. According to Jindo et al. [20], biochar as an ameliorant material made from a high-temperature pyrolysis process will have a large surface area structure. Besides, biochar also has aromatic $\mathrm{C}$ content that causes high water retention ability so that it can store and provide more water for plants.

3.3.5. Available Calcium. There was an interaction effect of biochar and shade on the available calcium content (Table 7$)$. The highest value $(0.39 \mathrm{Cmol}(+) / \mathrm{kg})$ was in the application of 10 ton/ha biochar at a 50\% light intensity. Meanwhile, the lowest value (of $0.21 \mathrm{Cmol}(+) / \mathrm{kg}$ ) resulted from control treatment at a $50 \%$ shade. According to Glaser et al. [21], in soils treated with biochar, base cations such as $\mathrm{Ca}^{2+}, \mathrm{Mg}^{2+}$, and $\mathrm{K}^{+}$are generally not bound by electrostatic forces in biochar. These cations are present as dissolved salts so that they can be absorbed and used by plants.

3.3.6. Available Magnesium. There was an interaction effect of biochar and shade on the available magnesium content (Table 8$)$. The highest content $(0.20 \mathrm{Cmol}(+) / \mathrm{kg})$ was in the B0 (without biochar) treatment at a 50\% light intensity. Meanwhile, the lowest one $(0.13 \mathrm{Cmol}(+) / \mathrm{kg})$ resulted from the application of 10 ton/ha biochar at a $50 \%$ shade. The addition of biochar to the soil had no effect on the available magnesium because the $\mathrm{Mg}^{2+}$ cation is not bound by electrostatic forces in the biochar. The base cation only acts 
TABLE 7: Effects of biochar and shade application on the available calcium $\left(\mathrm{cmol}(+) \cdot \mathrm{kg}^{-1}\right)$.

\begin{tabular}{lccccc}
\hline \multirow{2}{*}{ Shade (\%) } & \multicolumn{4}{c}{ Doses of biochar $\left(\right.$ ton ha ${ }^{-1}$ ) } & 15 \\
& $K$ & 0 & 10 & $0.27 \mathrm{bcd}$ & $0.25 \mathrm{bcde}$ \\
\hline 0 & $0.26 \mathrm{bcde}$ & $0.28 \mathrm{bc}$ & $0.21 \mathrm{e}$ & 0.25 \\
50 & $0.21 \mathrm{e}$ & $0.27 \mathrm{bcd}$ & $0.39 \mathrm{a}$ & $0.22 \mathrm{de}$ & $0.27 \mathrm{bcd}$ \\
70 & $0.28 \mathrm{bc}$ & $0.24 \mathrm{cde}$ & $0.24 \mathrm{cde}$ & $0.24 \mathrm{cde}$ & $0.30 \mathrm{~b}$ \\
Mean & 0.25 & 0.26 & 0.28 & 0.24 & 0.27 \\
\hline
\end{tabular}

${ }^{*}$ Means followed by the same letters are not significantly different at 5\% DMRT.

TABLE 8: Effects of biochar and shade application on the available magnesium $\mathrm{cmol}(+) \cdot \mathrm{kg}^{-1}$.

\begin{tabular}{lcccccc}
\hline \multirow{2}{*}{ Shade (\%) } & \multicolumn{5}{c}{ Doses of biochar (ton ha ${ }^{-1}$ ) } & Mean \\
\hline 0 & $K$ & 0 & 01 & $0.13 \mathrm{~cd}$ & $0.16 \mathrm{bc}$ & $0.16 \mathrm{~b}$ \\
50 & $0.15 \mathrm{bcd}$ & $0.15 \mathrm{bcd}$ & $0.13 \mathrm{~d}$ & $0.15 \mathrm{bcd}$ & $0.17 \mathrm{~b}$ \\
70 & $0.16 \mathrm{~b}$ & $0.20 \mathrm{a}$ & $0.15 \mathrm{bcd}$ & $0.15 \mathrm{bcd}$ & $0.16 \mathrm{~b}$ & 0.16 \\
Mean & $0.17 \mathrm{~b}$ & $0.16 \mathrm{bc}$ & 0.17 & 0.15 & 0.16 \\
\hline
\end{tabular}

${ }^{*}$ Means followed by the same letters are not significantly different at 5\% DMRT.

TABLE 9: Effects of biochar and shade application on ammonium $\mathrm{mg} / \mathrm{kg}$.

\begin{tabular}{|c|c|c|c|c|c|c|}
\hline \multirow{2}{*}{ Shade $(\%)$} & \multicolumn{5}{|c|}{ Doses of biochar (ton $\mathrm{ha}^{-1}$ ) } & \multirow{2}{*}{ Mean } \\
\hline & K & 0 & 10 & 15 & 20 & \\
\hline 0 & $264.83 \mathrm{~g}$ & $1151.98 \mathrm{~cd}$ & $1156.65 \mathrm{~cd}$ & $1504.21 \mathrm{ab}$ & $887.38 \mathrm{de}$ & 815.54 \\
\hline 50 & $294.86 \mathrm{~g}$ & $991.01 \mathrm{~d}$ & $1543.21 \mathrm{ab}$ & $1692.69 \mathrm{a}$ & $1687.25 \mathrm{a}$ & 1241.8 \\
\hline 70 & $352.41 \mathrm{fg}$ & 626.54 ef & $1361.84 \mathrm{bc}$ & $1363.48 \mathrm{bc}$ & $1394.70 \mathrm{abc}$ & 1019.8 \\
\hline Mean & 304.03 & 923.18 & 1353.9 & 1520.13 & 1323.11 & + \\
\hline
\end{tabular}

* Means followed by the same letters are not significantly different at 5\% DMRT.

as a dissolved salt that is then available and can be absorbed by plants [21].

3.3.7. Available Nitrogen. Based on the analysis of variance on the content of ammonium $\left(\mathrm{NH}_{4}^{+}\right)$and nitrate $\left(\mathrm{NO}_{3}^{-}\right)$, the addition of biochar could increase the available $\mathrm{N}$ (Tables 9 and 10). The highest available $\mathrm{N}$ in the form of ammonium (of $1687.25 \mathrm{mg} / \mathrm{kg}$ ) was in the application of 20 ton/ha biochar at a $50 \%$ shade. Meanwhile, the lowest value $(294.86 \mathrm{mg} / \mathrm{kg})$ resulted from control treatment at a $50 \%$ shade. In the form of nitrate, the highest available $\mathrm{N}$ content $(762.85 \mathrm{mg} / \mathrm{kg})$ was in the application of $15 \mathrm{ton} / \mathrm{ha}$ biochar, while the lowest value (at $438.40 \mathrm{mg} / \mathrm{kg}$ ) was obtained in the control treatment without biochar. Biochar, with its functional groups and pores, can maintain nitrogen availability in the soil and release nitrogen slowly according to the plant needs.

According to Bandosz (2006), the large surface area possessed by biochar containing several functional groups causes retention of $\mathrm{NH}_{3}$. By converting $\mathrm{NH}_{3}$ to its alkaline gas form, the acidic surface groups in the biochar can protonate $\mathrm{NH}_{3}$ to $\mathrm{NH}^{+}$. The addition of soil amendments such as biochar can retain $\mathrm{NO}_{3}^{-}$at the anion exchange site so that it can reduce $\mathrm{NO}_{3}^{-}$loss in the soil, thus available to plants [5].
3.3.8. Total Nitrogen. Based on the results of the analysis of variance, the application of biochar increased the total nitrogen content in the soil (Table 11), although a low total nitrogen content was also found in the biochar treatment. The highest total nitrogen content $(0.15 \%)$ resulted from the application of 10 ton/ha biochar treatment of $0.15 \%$, while the lowest content $(0.11 \%)$ resulted from the application of 15 and 20 ton/ha biochar. Despite the low total nitrogen content, biochar can store nitrogen and make it available to plants in high amounts. Biochar can also retain $\mathrm{N}$ and $\mathrm{P}$ elements so that they are not easily carried away by water because of the high waterholding ability of biochar, which reduces leaching [22]. Besides, biochar can increase soil moisture, thereby stimulating $\mathrm{N}$ mineralization to increase inorganic $\mathrm{N}$ that can be absorbed by plants.

\subsection{Effects of Biochar and Shade Application on Plant Growth}

3.4.1. Plant Height. Based on Figure 1, plants given biochar treatment showed a linear increase in plant height. The highest plant height was obtained in the plants treated with 10 ton/ha biochar at a 50\% shade. Meanwhile, the lowest plant height was obtained in the plants treated with 10 ton/ ha biochar at a without shading. Plant growth, especially 
TABLE 10: Effects of biochar and shade application on nitrate $(\mathrm{mg} / \mathrm{kg})$.

\begin{tabular}{|c|c|c|c|c|c|c|}
\hline \multirow{2}{*}{ Shade (\%) } & \multicolumn{5}{|c|}{ Doses of biochar (ton $\mathrm{ha}^{-1}$ ) } & \multirow{2}{*}{ Mean } \\
\hline & $\mathrm{K}$ & 0 & 10 & 15 & 20 & \\
\hline 0 & 357.23 & 543.96 & 566.97 & 711.17 & 740.18 & $583.9 \mathrm{a}$ \\
\hline 50 & 488.21 & 641.67 & 627.59 & 859.36 & 607.00 & $644.77 \mathrm{a}$ \\
\hline 70 & 469.78 & 655.45 & 724.63 & 718.02 & 841.23 & $681.82 \mathrm{a}$ \\
\hline Mean & $438.4 \mathrm{c}$ & $613.69 \mathrm{~b}$ & $639.73 \mathrm{ab}$ & $762.85 \mathrm{a}$ & $729.47 \mathrm{ab}$ & - \\
\hline
\end{tabular}

${ }^{*}$ Means followed by the same letters are not significantly different at 5\% DMRT.

TABLE 11: Effects of biochar and shade application on total nitrogen content (\%).

\begin{tabular}{|c|c|c|c|c|c|c|}
\hline \multirow{2}{*}{ Shade (\%) } & \multicolumn{5}{|c|}{ Doses of biochar (ton $\mathrm{ha}^{-1}$ ) } & \multirow{2}{*}{ Mean } \\
\hline & $K$ & 0 & 10 & 15 & 20 & \\
\hline 0 & 0.12 & 0.16 & 0.18 & 0.13 & 0.11 & $0.14 \mathrm{a}$ \\
\hline 50 & 0.16 & 0.18 & 0.13 & 0.11 & 0.11 & $0.14 \mathrm{a}$ \\
\hline 70 & 0.14 & 0.15 & 0.14 & 0.09 & 0.11 & $0.13 \mathrm{a}$ \\
\hline Mean & $0.14 \mathrm{ab}$ & $0.16 \mathrm{a}$ & $0.15 \mathrm{a}$ & $0.11 \mathrm{~b}$ & $0.11 \mathrm{~b}$ & - \\
\hline
\end{tabular}

* Means followed by the same letters are not significantly different at 5\% DMRT.

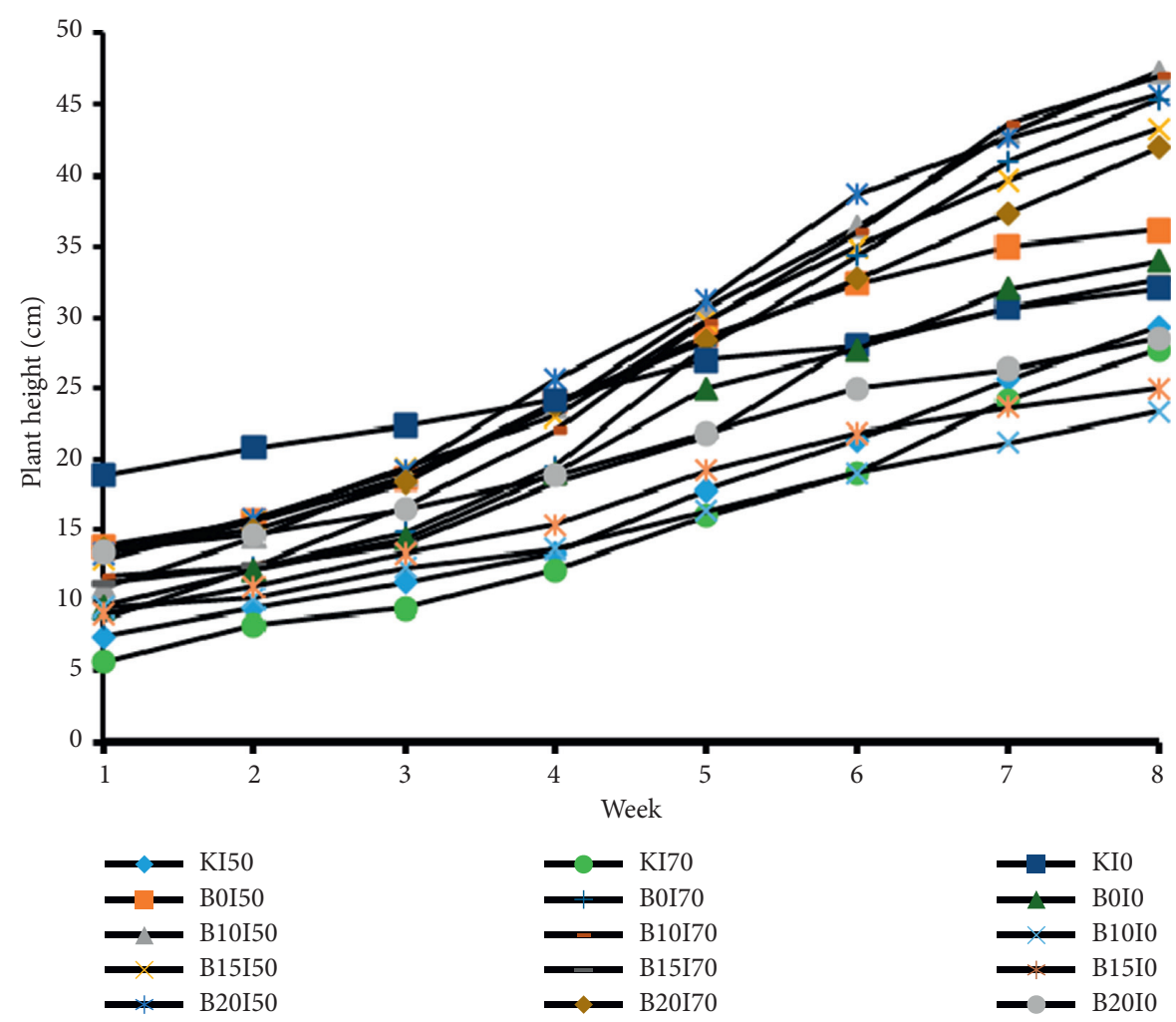

FIGURE 1: Plant height of longevity spinach as affected by biochar and shade application.

plant height, is influenced by several factors, one of which is the availability of nutrients in the soil for photosynthesis and other physiological processes. Longevity spinach (Gynura procumbens) is a shade-tolerant medicinal plant. According to Dan Azis [23], providing shade will also inhibit the light intensity accepted by plants, causing the vegetative phase of the plant to be more extensive compared to the plants that receive greater light.
3.4.2. Number of Leaves. The number of leaves observed was varied because it was not homogenous at the initial observation (Figure 2). Thus, there was a difference in the number of leaves every week. According to Sakinah et al. [24], the number of leaves and the number of branches in Gynura procumbens are influenced by light intensity and relative humidity. The increase in sunlight intensity is followed by an increase in the number of branches that will be 


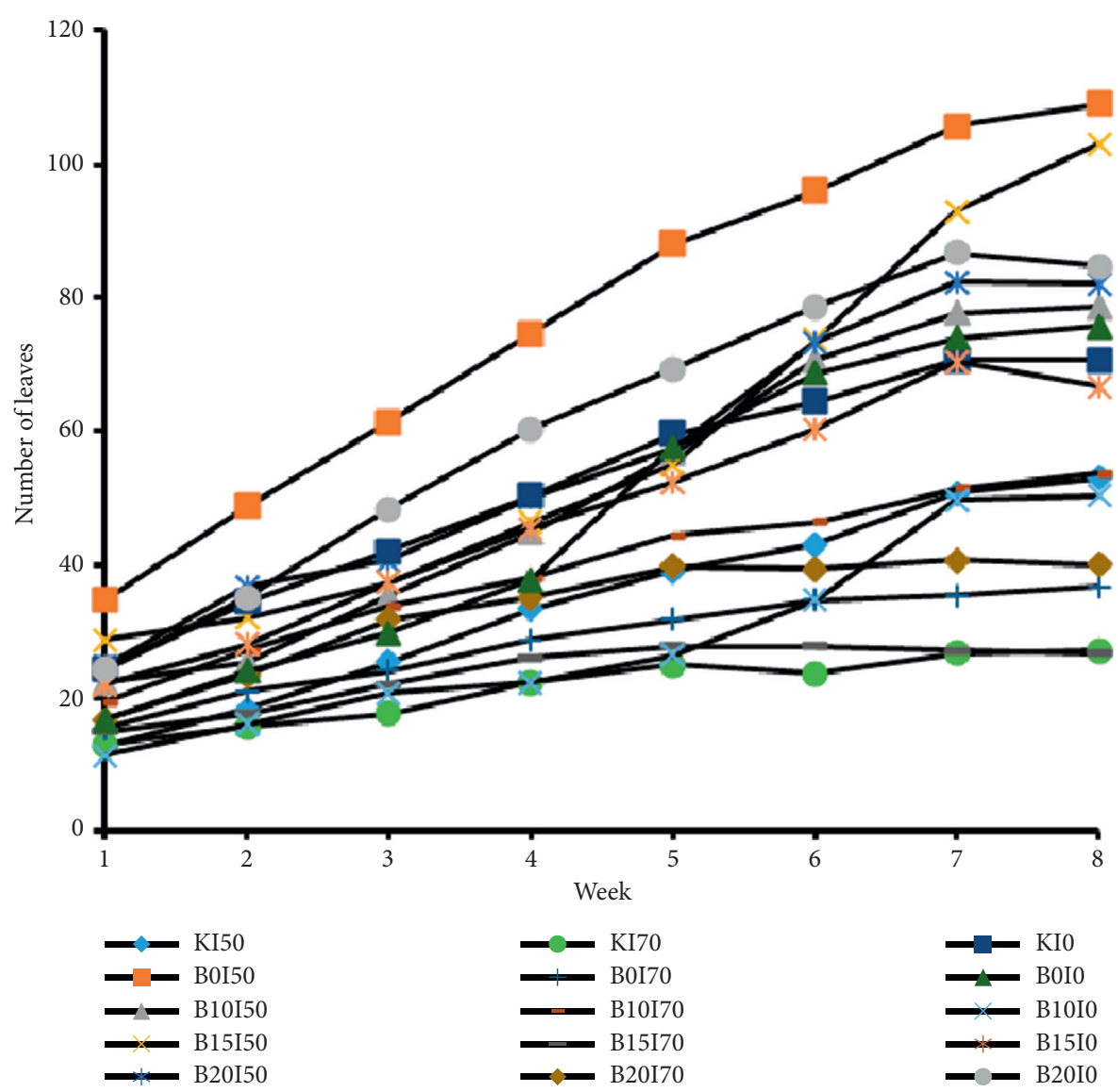

Figure 2: Number of leaves of longevity spinach (Gynura procumbens) plants as affected by biochar and shade application.

followed by the growth of young leaves. Meanwhile, the increase in relative humidity will decrease the number of branches, which then will affect the growth of leaves in the branches, consequently affecting the number of leaves as well.

3.4.3. Shoot and Root Fresh Weight. The highest shoot fresh weight resulted from the application of 15 ton/ha biochar at a 50\% light intensity. Meanwhile, the lowest shoot fresh weight was obtained in the plants with control treatment at a $70 \%$ shade (Figure 3). The highest root fresh weight was obtained in the control treatment with a $50 \%$ shade, while the lowest root fresh weight was obtained in the pants treated with 15 ton/ha biochar at $70 \%$ shade (Figure 4 ). Fresh weight describes the photosynthate content or the result of the photosynthesis process in the plant. Plant fresh weight can be influenced by several factors such as sunlight intensity, soil nutrient content, and soil moisture content, which can affect the nutrient absorption process and nutrient availability in the plant.

3.4.4. Shoot and Root Dry Weight. The highest shoot dry weight resulted from the application of 10 ton/ha biochar at a $100 \%$ light intensity, while the lowest was obtained in the control treatment with a $70 \%$ shade (Figure 5 ). The highest root dry weight was obtained in the control treatment without shading.

Meanwhile, the lowest root dry weight resulted from the application of 15 ton/ha biochar with a $70 \%$ shade (Figure 6). The nutrient element that has the most influence on plant dry weight content is P. The higher the uptake of $\mathrm{P}$ by plants, the higher the uptake of other elements. The more nutrients that can be absorbed by plants, the higher the plant dry weight. Besides, the dry weight of plants is also influenced by water contained in the tissue biomass [25].

3.5. Total Nitrogen in Plant Tissues. There was an interaction effect of biochar and shade on the total nitrogen content in plant tissues (Table 12). The highest nitrogen content in plant tissues $(3.15 \%)$ was in the plants treated with 15 ton/ha biochar with a $70 \%$ shade. Meanwhile, the lowest value $(1.73 \%)$ was obtained in the control treatment without shading. Nitrogen content in plant tissues can indicate protein and nucleic acid synthesis, which can play a role in the formation of new cells in plant growth.

According to Pradnyawan et al. [26], Gynura procumbens plants under $70 \%$ shade condition produce the highest nitrogen content compared to those under $50 \%$ and $0 \%$. It is because, under $70 \%$ shade conditions, there is a buildup of nitrogen in the form of $\mathrm{NH}_{4}^{+}$and $\mathrm{NO}^{-}$in plant 


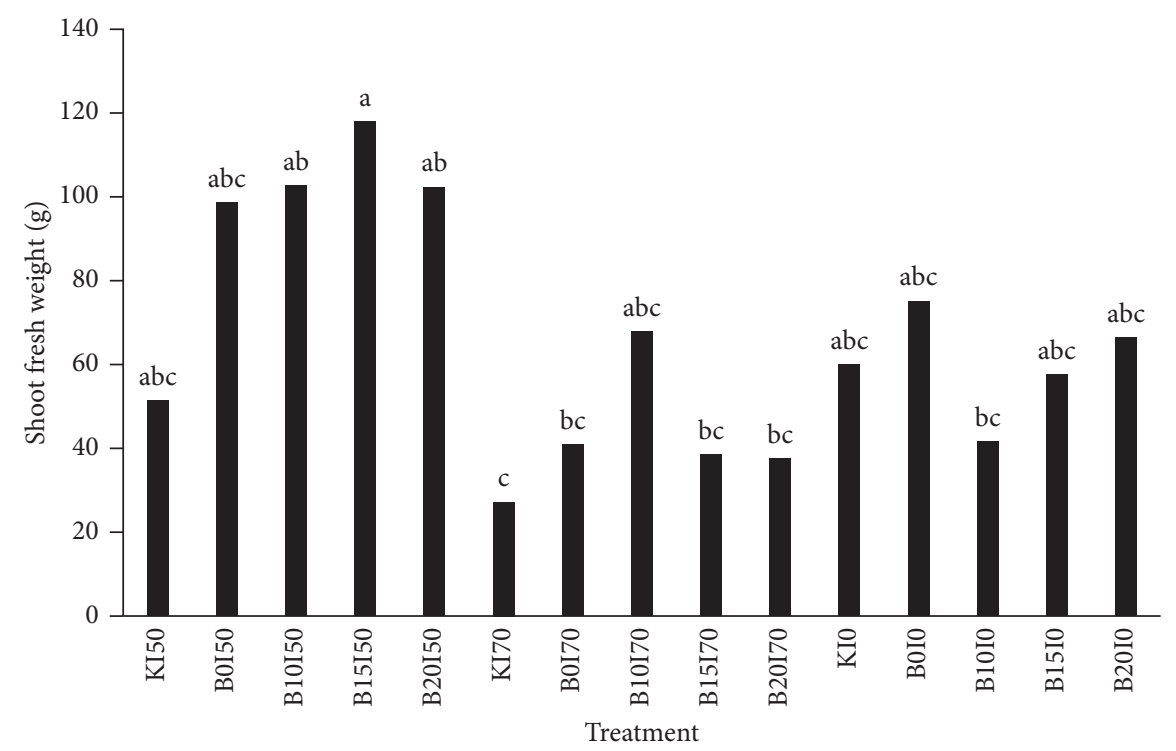

FigURE 3: Shoot fresh weight of longevity spinach (Gynura procumbens) plants as affected by biochar and shade application.

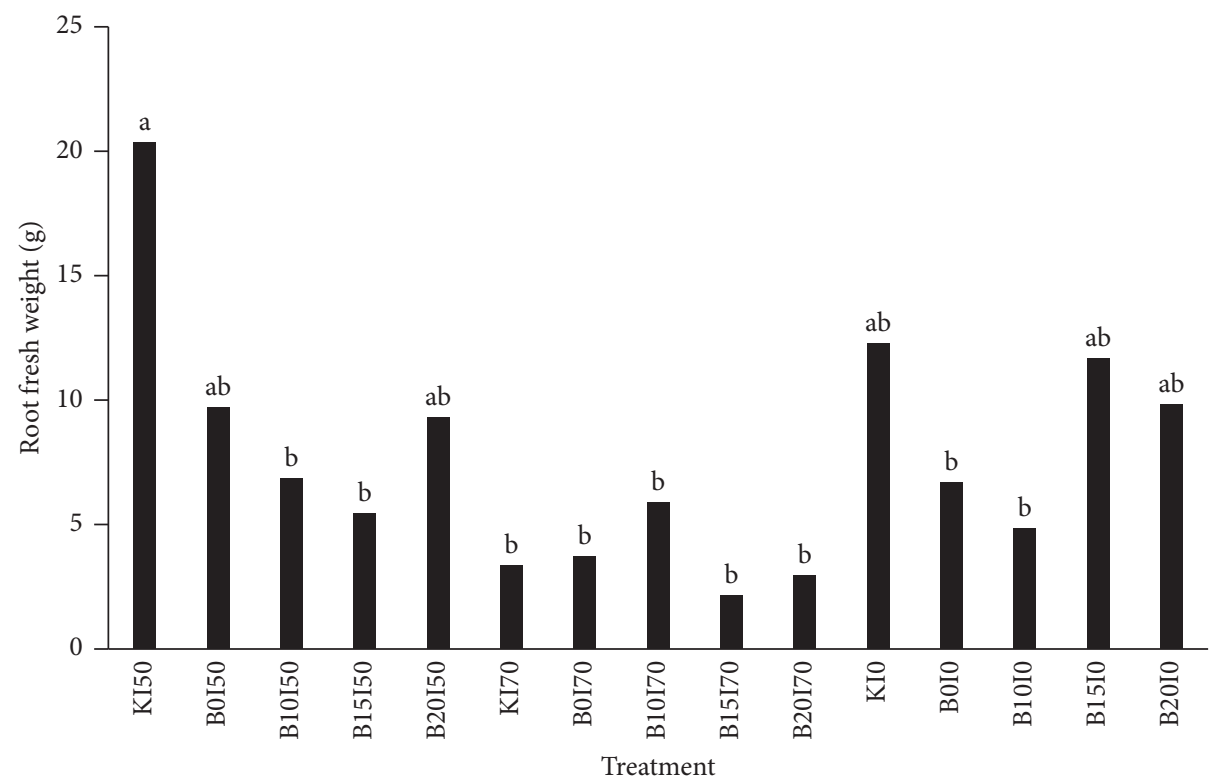

FIGURE 4: Root fresh weight of longevity spinach (Gynura procumbens) plants as affected by biochar and shade application.

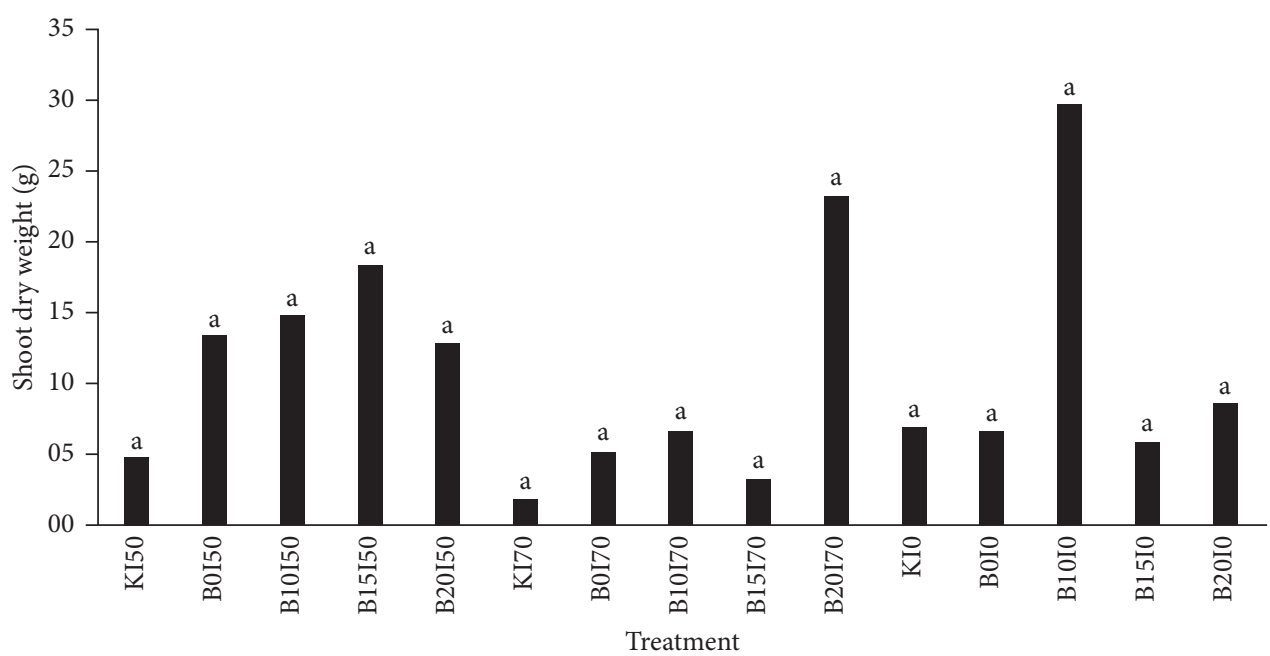

FIGURE 5: Shoot dry weight of longevity spinach (Gynura procumbens) plants as affected by biochar and shade application. 


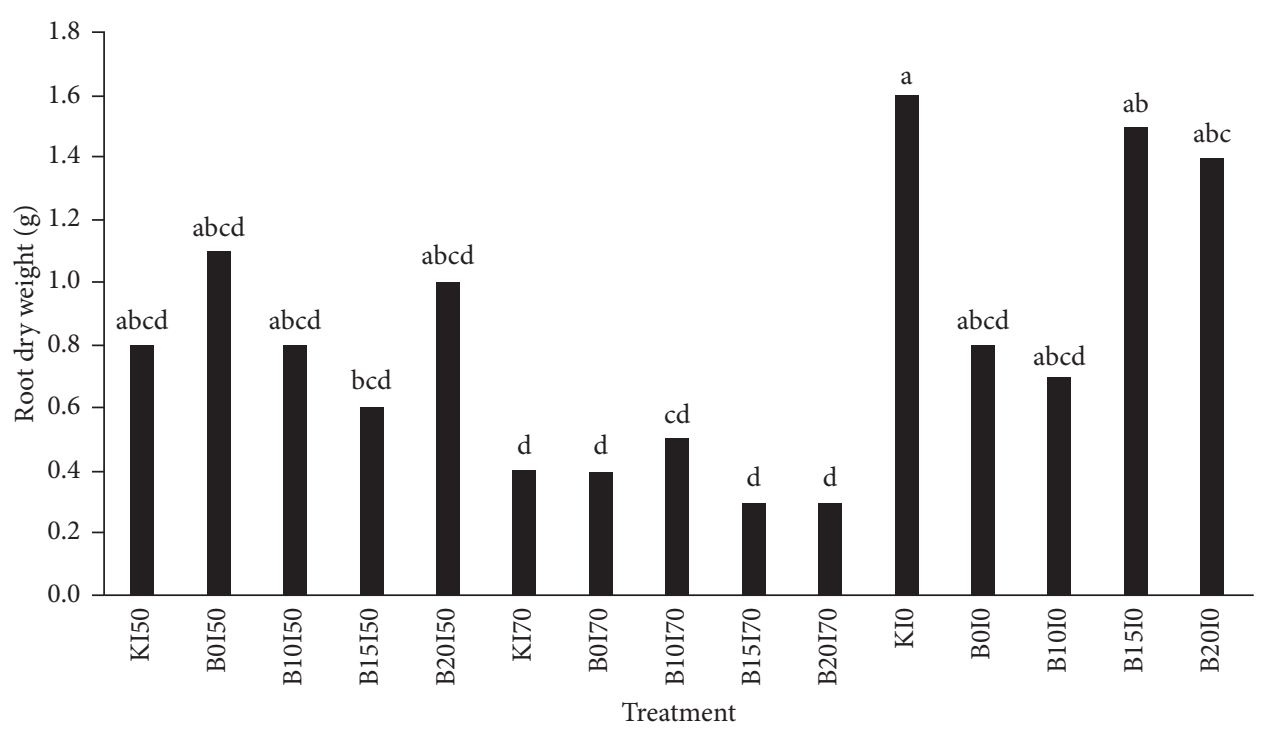

FIGURE 6: Root dry weight of longevity spinach (Gynura procumbens) plants as affected by biochar and shade application.

TABLE 12: Effects of biochar and shade application on total $\mathrm{N}$ in plant tissues (\%).

\begin{tabular}{|c|c|c|c|c|c|c|}
\hline \multirow{2}{*}{ Shade (\%) } & \multicolumn{5}{|c|}{ Doses of biochar $\left(\right.$ ton $\mathrm{ha}^{-1}$ ) } & \multirow{2}{*}{ Mean } \\
\hline & $K$ & 0 & 10 & 15 & 20 & \\
\hline 0 & $1.73 \mathrm{~g}$ & $2.41 \mathrm{cdef}$ & $2.68 \mathrm{abcd}$ & $2.25 \mathrm{def}$ & $2.07 \mathrm{fg}$ & 2.23 \\
\hline 50 & 2.60 bcde & $2.20 \mathrm{efg}$ & $2.14 \mathrm{efg}$ & $2.53 \mathrm{cdef}$ & $2.13 \mathrm{efg}$ & 2.32 \\
\hline 70 & $2.88 \mathrm{abc}$ & $3.05 \mathrm{ab}$ & $2.84 \mathrm{abc}$ & $3.15 \mathrm{a}$ & $3.06 \mathrm{ab}$ & 2.99 \\
\hline Mean & 2.4 & 2.55 & 2.55 & 2.64 & 2.42 & + \\
\hline
\end{tabular}

${ }^{*}$ Means followed by the same letters are not significantly different at 5\% DMRT.

glutamine. The light produced by $70 \%$ shade is not sufficient for plants to convert the nitrogen source into organic nitrogen, which is then used in plant metabolism.

3.6. Quercetin. There was a significant effect of the treatments given on the quercetin content. Each treatment given produced different results in the quercetin content of Gynura procumbens plants. The highest quercetin content $(0.51 \%)$ resulted from the application of 15 ton/ha of biochar at a $70 \%$ shade conditions. Meanwhile, the lowest value $(0.29 \%)$ was obtained in the plants without biochar application at a $50 \%$ shade (Table 13 ).

According to Pradnyawan et al. [26], plant chlorophyll content, both chlorophyll a and chlorophyll b, will increase under $70 \%$ shade conditions. The same thing was conveyed by Amini et al. [27] that shaded plants will produce more chlorophyll, especially chlorophyll b, compared to plants without shade. The increase in chlorophyll content is a form of plant response to environmental stress as a mechanism to increase light interception under shaded environmental conditions. At different photosynthesis rates, it will certainly produce different quercetin compounds. By providing shade, it will increase production or accelerate the secondary metabolism of plants in response to environmental conditions that are not suitable for their habitat. Giving stress increases not only quercetin, but also
TABLE 13: Effects of biochar and shade application on the quercetin content (\%).

\begin{tabular}{lcccccc}
\hline \multirow{2}{*}{ Shade (\%) } & \multicolumn{6}{c}{ Doses of biochar $\left(\right.$ ton ha $\left.\mathrm{ha}^{-1}\right)$} \\
& $K$ & 0 & 10 & 15 & 20 & Mean \\
\hline 0 & $0.44 \mathrm{~b}$ & $0.48 \mathrm{ab}$ & $0.48 \mathrm{ab}$ & $0.47 \mathrm{ab}$ & $0.44 \mathrm{~b}$ & 0.46 \\
50 & $0.38 \mathrm{c}$ & $0.29 \mathrm{~d}$ & $0.33 \mathrm{~cd}$ & $0.37 \mathrm{c}$ & $0.37 \mathrm{c}$ & 0.35 \\
70 & $0.33 \mathrm{~cd}$ & $0.34 \mathrm{~cd}$ & $0.38 \mathrm{c}$ & $0.51 \mathrm{a}$ & $0.36 \mathrm{c}$ & 0.38 \\
Mean & 0.38 & 0.37 & 0.39 & 0.45 & 0.39 & + \\
\hline
\end{tabular}

${ }^{*}$ Means followed by the same letters are not significantly different at $5 \%$ DMRT.

several other flavonoid compounds that are produced to respond to environmental stress and adapt to these conditions. According to Lewis et al. [28], there is a decrease in photon absorption in a gradient in shaded plants. Shaded plants have a high total chlorophyll content because shaded conditions will encourage the absorption of the red light spectrum to be much higher so that it will encourage the production of chlorophyll a [29]. Chlorophyll b content indicates the amount of chlorophyll content used for metabolic processes but chlorophyll b synthesis is influenced by chlorophyll a. Therefore, under shaded conditions, not only quercetin changes but also other polyphenols such as kaempferol, myricetin, and others are caused by an increase in the amount of chlorophyll in shaded conditions. 
The administration of biochar could affect plant growth and quercetin production by fulfilling nutrients requirements for metabolism and photosynthesis. Several elements that influence plant metabolism include nitrogen, magnesium, and calcium, which are useful as building blocks for protein, chlorophyll, and enzymes that can accelerate plant metabolic processes.

\section{Conclusion}

The application of 15 ton/ha biochar combined with $50 \%$ shade could improve the growth of longevity spinach (Gynura procumbens) plants. Meanwhile, the application of 20 ton/ha biochar combined with $70 \%$ shade significantly increased the available $\mathrm{N}$ content in the soil to $1394.70 \mathrm{mg} /$ $\mathrm{kg}$. And addition of 15 ton/ha biochar with $70 \%$ shade increased the quercetin content by $0.51 \%$.

\section{Data Availability}

The data used to support the findings of this study are available from the corresponding author upon request.

\section{Conflicts of Interest}

The authors declare that they have no conflicts of interest.

\section{Authors' Contributions}

Sri Nuryani Hidayah Utami was responsible for the processing of budged funding, data analysis, manuscript writing, and addressing reviewers' comments, and revising the manuscript, Angga Prasetya coordinated the researchers, accessing data, directly involved in the research design and discussion of results, and manuscript writing, and Eko Hanudin guided laboratory measurements for soil characteristics, responding to reviewers' comments.

\section{Acknowledgments}

The authors are deeply grateful to the Universitas Gadjah Mada for providing budget and facilities within the framework of the RTA (Recognisi Tugas Akhir/Final Project Recognition Grant) with the Team Leader Sri Nuryani Hidayah Utami.

\section{References}

[1] V. J. Cheng, A. E.-D. A. Bekhit, M. McConnell, S. Mros, and J. Zhao, "Effect of extraction solvent, waste fraction and grape variety on the antimicrobial and antioxidant activities of extracts from wine residue from cool climate," Food Chemistry, vol. 134, no. 1, pp. 474-482, 2012.

[2] N. Kaewseejan and S. Siriamornpun, "Bioactive components and properties of ethanolic extract and its fractions from Gynura procumbens leaves," Industrial Crops and Products, vol. 74 , no. 15 , pp. 271-278, 2015.

[3] T. Morikawa, F. Xu, K. Ninomiya, H. Matsuda, and M. Yoshikawa, "Nigellamines A3, A4, A5, and C, new dolabellane-type diterpene alkaloids, with lipid metabolismpromoting activities from the Egyptian medicinal food black cumin," Chemical and Pharmaceutical Bulletin, vol. 52, no. 4, pp. 494-497, 2004.

[4] A. Abdurachman, A. Dariah, and D. A. Mulyani, "Strategi dan teknologi pengelolaan lahan kering mendukung pengadaan pangan nasional," Journal Litbang Pertanian, vol. 27, no. 2, pp. 43-49, 2008.

[5] Y. Yao, B. Gao, M. Zhang, M. Inyang, and A. R. Zimmerman, "Effect of biochar amendment on sorption and leaching of nitrate, ammonium, and phosphate in a sandy soil," Chemosphere, vol. 89, no. 11, pp. 1467-1471, 2012.

[6] L. Hua, W. Wu, Y. Liu, M. B. McBride, and Y. Chen, "Reduction of nitrogen loss and $\mathrm{Cu}$ and $\mathrm{Zn}$ mobility during sludge composting with bamboo charcoal amendment," Environmental Science and Pollution Research, vol. 16, no. 1, pp. 1-9, 2009.

[7] K. H. Markham, Cara Mengidentifikasi Flavonoid. (Edisi 2). Penerjemah: K. Padmaewinata dan I. Soediro. Bandung, Penerbit ITB, Bandung, Indonesia, 1988.

[8] M. M. B. Damanik, E. H. Bachtiar, F. Sarifuddin, and D H. Hamidah, Kesuburan Tanah Dan Pemupukan, USU Press, Logan, UT, USA, 2011.

[9] T. F. P. Hakim, P. Widodo, and E. Sudiana, "Variasi morfologi bambu tali [gigantochloa apus (schult.F.) kurz.] pada berbagai ketinggian tempat di Sub daerah aliran sungai pelus," Biosfera, vol. 32, no. 1, pp. 42-50, 2015.

[10] M. Arifin, Analisis Tanah Dan Tanaman, USU Press, Logan, UT, USA, 2007.

[11] K. Mengel and E. A. Kirkby, Principles of Plant Nutrition, International Potash Institute Worblaufen- Bern/Switzerland, Kunming, China, 2007.

[12] P. A. Sanchez, Properties and Management of Soils in the Tropics, John Wiley \& Sons, Hoboken, NJ, USA, 2004.

[13] J. L. Havlin, S. L. Tisdale, W. L. Nelson, and J. D. Beaton, Soil Fertility and Fertilizers, Prentice-Hall of India. Pvt Ltd, New Delhi, India, 6th edition, 2010.

[14] D. Foth, Fundamentals of Soil Science, John Wiley \& Sons, Hoboken, NJ, USA, 2010.

[15] S. Hardjowigeno, Ekologi Tanaman, USU Press, Logan, UT, USA, 2003.

[16] V. I. Putri, D. Mukhlis, and D. B. Hidayat, "Application of some type biochar for repairing the chemichal properties of ultisol and the growth of corn plants," Journal Agroekoteknologi FP USU, vol. 5, no. 4, pp. 824-828, 2017.

[17] E. Maftuah and D. Nursyamsyi, "Potensi berbagai bahan organik rawa sebagai sumber biochar," Journal Biodiversity, vol. 1, no. 4, pp. 776-781, 2015.

[18] M. B. Salawati and I. Kadekoh, A. R. Thaha, "Potency of rice husk biochar on modifying soil $\mathrm{pH}, \mathrm{CEC}, \mathrm{C}$ - organic and available $\mathrm{P}$ in wetland rice of inceptisols," The Agricultural Sciences Journal, vol. 23, no. 2, pp. 101-109, 2016.

[19] S. Herlambang, A. Z. Purwono, H. T. Sutiono, Y. M. Putra, S. Dan, and N. Rina, Penerapan Biochar Tempurung Kelapa Dan Bahan Limbah Organik Untuk Memperbaiki Tanah Inceptisol Potorono Yogyakarta, Seminar Nasional UPNV Yogyakarta, Yogyakarta, Indonesia, 2018.

[20] K. Jindo, H. Mizumoto, Y. Sawada, M. A. Sanchez-Monedero, and T. Sonoki, "Physical and chemical characterization of biochars derived from different agricultural residues," Biogeosciences, vol. 11, no. 23, pp. 6613-6621, 2014.

[21] B. Glaser, J. Lehmann, and W. Zech, "Ameliorating physical and chemical properties of highly weathered soils in the tropics with charcoal-a review," Biology and Fertility of Soils, vol. 35, no. 4, pp. 219-230, 2002.

[22] S. E. Hale, V. Alling, V. Martinsen, J. Mulder, G. D. Breedveld, and G. Cornelissen, "The sorption and desorption of 
phosphate- $\mathrm{P}$, ammonium- $\mathrm{N}$ and nitrate- $\mathrm{N}$ in cacao shell and corn cob biochars," Chemosphere, vol. 91, no. 11, pp. 1612-1619, 2013.

[23] W. Dan Azis, "Pengaruh naungan sengon (falcataria moluccana L.) dan pemupukan terhadap pertumbuhan ganyong putih (canna edulis ker.)," Journal Silvikutlur Tropika, vol. 4, no. 2, pp. 62-68, 2013.

[24] D. G. Sakinah, E. T. Susila Putra, and R. Rogomulyo, "Produksi dan kadar flavonoid daun sambung nyawa (Gynura procumbens (lour.) merr.) pada tiga fase agroforestri," Vegetalika, vol. 7, no. 3, pp. 1-15, 2018.

[25] S. Winarso, Kesuburan Tanah, Penerbit Gava Media, Yogyakarta, Indonesia, 2005.

[26] S. W. H. Pradnyawan, W. Mudyantini, and M. Marsusi, "Growth, nitrogen, chlorophyll, and carotenoid content of Gynura procumbens (Lour) Merr. leaves at different shade," Biofarmasi Journal of Natural Product Biochemistry, vol. 3, no. 1, pp. 7-10, 2005.

[27] S. P. Amini, C. J. Soegihardjo, and D. H. Hartiko, Biokimia Tumbuhan, PAU Bioteknologi UGM, Yogyakarta, Indonesia, 1990.

[28] J. D. Lewis, R. B. McKane, D. T. Tingey, and P. A. Beedlow, "Vertical gradients in photosynthetic light response within an old-growth douglas-fir and western hemlock canopy," Tree Physiology, vol. 20, no. 7, pp. 447-456, 2000.

[29] F. B Salisbury and D. C. W. Ross, Fisiologi Tumbuhan. Jilid 3. Bandung, Penerbit ITB, Yogyakarta, Indonesia, 1995. 